\title{
Marching for science
}

\begin{abstract}
The UCLA community, together with the UK-based Pro-test movement and the US campaign group Speaking of Research, is organizing a demonstration in support of animal research. The experience of scientists in the UK suggests that this approach can help stem the tide of rising violence against researchers.
\end{abstract}

I n early March, David Jentsch, a primate researcher working on the mechanisms of action of psychotherapeutic drugs, joined the lengthening list of UCLA researchers that have been targeted by animal right extremists when his car was firebombed outside of his home. Unlike previous victims, however, Dr. Jentsch responded by taking the bold step of organizing a UCLA chapter of the UK-based, pro-animal research campaign group Pro-test. Pro-test's very public demonstrations in support of continued animal research in the UK have been crucial in changing the climate of fear that many UK researchers lived in. Reassuringly, the UCLA administration has taken an equally robust stand, suing a group of activists earlier this year to stop them harassing UCLA researchers. We applaud both of these measures and hope that other US institutions follow UCLA's lead, both by publicly demonstrating their considerable support for animal research and by taking proactive action to prevent animal extremists targeting legitimate research.

The Animal Liberation Front, which has previously targeted several other UCLA researchers, claimed responsibility for the attack and also threatened Jentsch in a personal message that they would "come for you when you least expect it and do a lot more damage than to your property." Nor have these attacks been limited to researchers working with primates: last year, the home of David Feldheim, a University of California Santa Cruz scientist working on the connectivity of the visual system in mice, was firebombed.

Other victims of these attacks, such as Edythe London, another UCLA researcher, have responded by publicly defending their work and explaining the importance of using animals in research in newspapers. However, this is not a battle that can be won entirely by reasoned discussion in the media. Scientists, used to debating their disagreements through rational discussion, often feel that the same tactic should work to convince the public of the need for animal research; if only the public understood why we do animal research, they would of course be supportive of it. Unfortunately, such rational discussion has been unsuccessful with the hard core of animal rights activists.

Sadly, these sort of extremist voices currently dominate the public discourse on the ethics of animal research, especially in the form of very public demonstrations demonizing scientists who use animals in their research. These campaigns usually feature emotive pictures of monkeys, cats and dogs. This sort of emotional appeal does seem to be successful in persuading substantial numbers of people to align themselves against animal research, even though their own views, if thought out, might be very different from the extreme aims that are espoused by the most active animal rights advocates. For a disinterested layman living in a university town, these emotive images in a loud, public demonstration may well form the dominant impression of what animal work is all about, whereas the cogent arguments in support of such work remain unread in a newspaper or journal.

This is what makes Jentsch's call for a public demonstration in support of animal research all the more important. Jentsch and the new UCLA Pro-test chapter, together with US-based pro-research campaign group Speaking of Research, are organizing a march on April 22, set to coincide with a regular demonstration organized by the activist group Stop Animal Experimentation Now. Together with Tom Holder, one of the founding members of Pro-test, Jentsch has asked faculty, students and staff to participate in this public demonstration in support of animal research (http://www.ucla-pro-test.org/).

Undoubtedly, law enforcement agencies and universities should also tackle animal rights terrorism head-on. The response of law enforcement agencies in both the UK and US has improved tremendously, with UK law enforcement taking proactive action to prevent researchers being targeted in the first place. The US has also recently enacted tougher laws to deal with such violent activists, such as the Animal Enterprise Terrorism Act in 2006 and the Researcher Protection Act of 2008. UCLA has responded to the escalating violence against its scientists by suing the UCLA Primate Freedom Project, the Animal Liberation Front and the Animal Liberation Brigade, as well as several individuals believed to be affiliated with these groups. The university is seeking an injunction that would prohibit these groups from committing or threatening violence against UCLA personnel, vandalizing property or publicly posting personal information about UCLA personnel. Similar injunctions have had some success in the UK, reducing the harassment of researchers at Huntingdon Life Sciences in Cambridge.

Critically, however, it is imperative that we take back some of the public discourse on animal research in the form of open demonstrations. Jentsch feels that most of the annual anti-animal research demonstrators at UCLA are not from the university at all, a statement which is supported by a 2005 survey finding that $86 \%$ of the students in Oxford, another bastion of regular animal rights protests, actually supported work in animals. A public demonstration by the silent, law-abiding majority is an important part of standing up to the bullying of animal rights terrorists. In the UK, the Pro-test movement was the catalyst in getting government ministers and the then Prime Minister Tony Blair to speak out in support of animal testing, suggesting that public protests are critical for encouraging other public figures to support research. Only when we dare to speak out in defense of animal research ourselves can we expect other, less directly involved public figures to take a stance as well. We wish the fledgling US Pro-Test movement the best and encourage all scientists to take similar steps in standing up for science.

View more background material on Connotea at http://connotea.org/user/ NatNeurosci/tag/editorial200905. 